\title{
電子カルテとリンクした持参薬管理システムの
} 構築と医師・看護師による評価

辻 泰弘 $^{* 1}$, 平木洋一 ${ }^{2}$, 溝口晶子 ${ }^{1}$, 曽根本恵美 ${ }^{1}$, 平田俊子 ${ }^{3}$, 横山吉博 ${ }^{4}$, 平尾幸一 ${ }^{4}$, 神村英利 ${ }^{5}$, 加留部善晴 ${ }^{5}$

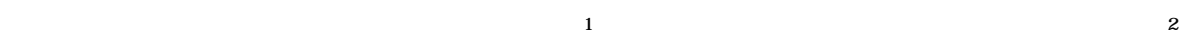
医療法人白十字会佐世保中央病院看護部 ${ }^{3}$, 医療法人白十字会経営企画統括本部 ${ }^{4}$, 福岡大学薬学部 ${ }^{5}$

\section{Development of System Utilizing Electronic Medical Records for Management of Medicines Brought to Hospital by Inpatients and Its Evaluation by Doctors and Nurses}

\author{
Yasuhiro Tsuji ${ }^{* 1}$, Yoichi Hiraki ${ }^{2}$, Akiko Mizoguchi $^{1}$, Emi Sonemoto $^{1}$, Toshiko Hirata ${ }^{3}$, \\ Yoshihiro Yokoyama ${ }^{4}$, Koichi Hirao ${ }^{4}$, Hidetoshi Kamimura ${ }^{5}$ and Yoshiharu Karube ${ }^{5}$ \\ Department of Pharmacy, Sasebo Chuo Hospital ${ }^{1}$ \\ Department of Pharmacy, National Hospital Organization Nagasaki Medical Center ${ }^{2}$ \\ Department of Nursing, Sasebo Chuo Hospital ${ }^{3}$ \\ Headquarters for Management Planning, Hakujyujikai Medical Corporation ${ }^{4}$ \\ Faculty of Pharmaceutical Sciences, Fukuoka University ${ }^{5}$
}

\author{
$\left[\begin{array}{l}\text { Received September 12, } 2008 \\ \text { A ccepted May 11, } 2009\end{array}\right]$
}

Information is essential in the risk management of treatment after admission. With this in mind, we created a system allowing information regarding medicines brought to hospital by inpatients to be shared among hospital medical staff. It is based on electronic medical records and permits the administration of medicines patients have brought to hospital to be confirmed following their admission. In the present study, we gave a questionnaire to doctors and nurses so that they could evaluate the functionality of the system. The results were evaluated using customer satisfaction (CS) analysis. We also examined the amount of reduction in drug purchase costs through the use of medicines brought to hospital by inpatients. For doctors, CS analysis showed that the display of medicines brought to hospital by inpatients on an electronic medical record screen required improvement. For nurses, the results of CS analysis indicated that they were satisfied with the system's functionality. Use of medicines brought to hospital by inpatients after admission led to average monthly savings in hospital drug purchase costs of 1,345,473 yen. In conclusion, our risk management system has high utility in view of its functionality and contribution to improving hospital management.

Key words — medicines brought by inpatients, medicine identification, electronic medical record, customer satisfaction analysis

緒言

日本病院薬剂師会から 2005 年 1 月に「入院時患者持 参薬に関する薬剂師の対応について」が通達され, 薬剤 師は持参薬管理に積極的に関与し, 患者の安全確保を担 うことが望まれている.特に近年, Diagnosis Procedure Combination(DPC)を導入する病院が増えており ${ }^{1)}$,この ような医療機関では医療安全と経費節減の両面から，薬 剂師による持参薬管理が強く求められている.
佐世保中央病院(以下，本院と略す)ではDPC を導入 した 2006 年から，持参薬を有効利用するために全入院 患者を対象に, 薬剂師による持参薬鑑別を実施してき た、しかし，これらは紙媒体での情報であったため，鑑 別後の持参薬がどのような割合で実施され，かつ，指示 通りに実施されているか否かを確認することができな かった.

このような状況を改善すべく，薬斉師が入力した持参 薬情報を医療スタッフ全員が共有しやすく，加えて指示 ミスや与薬ミスを防止するために持参薬投与の実施確認 
が可能な持参薬管理システム(以下，本システムと略す) を電子カルテ内に構築した . 乥こで, 本システムの機能 性について，医師・看護師を対象としたアンケート調査 による Customer Satisfaction(CS)分析を試みた .さらに は, 持参薬継続投与による医薬品購入費の節減額につい ても検討を行ったので，あわせて報告する．

\section{方法}

本院は 312 床の地域医療支援病院である. 2007 年度 (平成 19 年度)の 1 日平均新規入院患者数は 14.9 人, 平 均在院日数は 15.7 日で, 薬斉師は 9 名が常勤している. 本院では「患者が入院時に病院に持参した他院および他 診療科等から処方された医薬品，または自診療科外来で 処方された医薬品」を持参薬と定義している．持参薬を 有する患者の入院時には, 薬冏師が面談して医薬品に関 する情報収集を行い，医師による処方や医薬品に関する 指示出しは，持参薬情報を確認後に行うことを原則とし ている.また, 持参薬の医薬品名, 用法・用量が薬袋, 診療情報提供書, お薬手帳および患者面談でも判別でき ない場合は，紹介・処方先の施設に必ず問い合わせを行 い，持参薬の情報収集に努めている。一方，一度調剂さ れた医薬品を再び加工することに関して規定の用語が存 在しないため，本稿では「再調剂」という表記で統一し た . 再調斉は医師の指示が必要であることから，本院で は医師の「持参薬再調剂指示せん」に基づいて再調剂を 行っている，なお，散剂，水剂，粉砕調剂された錠斉の 持参薬再調剂は行っていない。

1. 持参薬管理システムの構築

本システムは電子カルテを中心にオーダリングシステ ムならびに各部門システムを統合した総合医療情報シス テムHOMES(自社開発)内に構築し，2008年 3 月より本 格稼働した．電子カルテサーバーのO Operating System (OS)は Microsoft ${ }^{\circledR}$ Windows Server 2003 R2 SP1, 電子力 ルテ端末のOSは Microsoft ${ }^{\circledR}$ Windows XP Professional 2002 SP2, データベースはORACLE ${ }^{\circledR} 9 i$, 医薬品情報源に は MDbank((株)ユヤマ)を用い，2008年 3月下旬から本 格稼動した。なお，これらはオーダリングシステムなら びに電子カルテ構築時に導入した物的資材であり，本シ ステム構築に際して新たな資材導入費用は発生しなかっ た．電子カルテとリンクした本システムの持参薬入力か ら実施までの全体的なシステムフローを図 1 に示す．

1)持参薬鑑別結果の電子カルテ入力

本院電子カルテにおける持参薬情報の入力画面を図 2 に示す.MDbank は官報告示から約1カ月後には，先 発・後発医薬品にかかわらずすべての医薬品をデータ ベースに収載している，乥こで本院では，極力最新の医 薬品情報を反映するために，MDbank のデータベースを 毎月更新しており，運用開始から現在(2009年 2 月時点) までに鑑別不可能な持参薬はなかった(後発医薬品を含

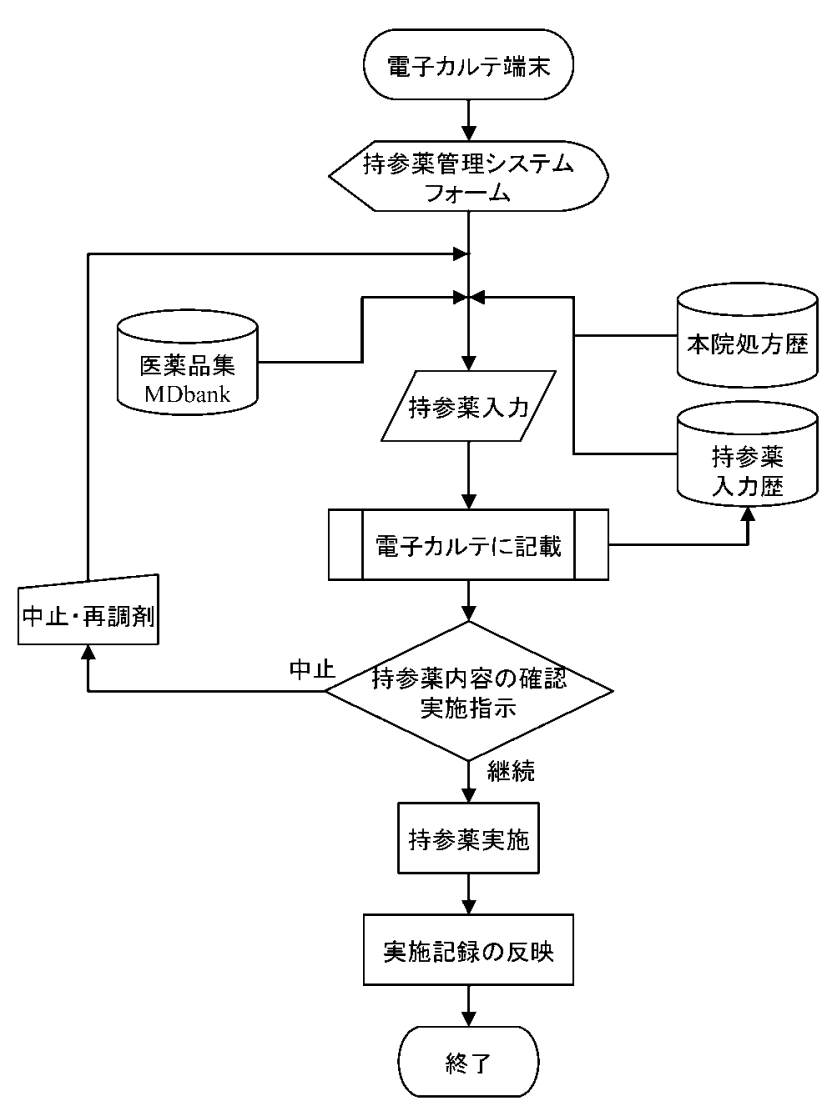

図 1 . 本システムのシステムフロー

めた検索のヒット率は $100 \%)$. 院内すべての電子カル テ端末から薬阂師は持参薬情報の入力，閲覧および修正 ができ，医師は持参薬情報の閲覧，看護師は持参薬の投 与実施入力と光の確認ができるようにした . また，電子 カルテに医薬品名検索機能(一般名, 製品名, 識別本体 コード，識別包装コード)および薬効検索機能を搭載し た .さらに，本院処方歴および持参薬入力歴が存在する 場合の検索機能も追加した . 持参薬の継続・中止の指示 を図 2 右側のチェックボックスで行えるようにした . 持 参薬の投与実施確認を正確に行えるようにするため，用 法・用量および服用日の入力には，本院処方オーダリン グシステムを流用した．また，服用日を指定することで 1週間に 1 度しか服用しない医薬品，服用が透析日に限 定される医薬品および手術前に休薬を必要とする医薬品 等への対応も可能とした .

2)持参薬確認および投与実施

持参薬確認および投与実施画面を図 3 に示す . 持参薬 が院内採用医薬品と一致する場合は医薬品名の後に 【採】のマークを表示し，医師・看護師が非採用医薬品 と区別できるようにした . 持参薬情報は日付・用法ごと に表示し，患者の持参薬服用を確認した看護師が所定の チェックボックスに入力することにより，院内処方薬と ともに薬歴管理される.これらの持参薬情報はカレン ダー形式で表示されるため, 服用終了日や残数の把握が 


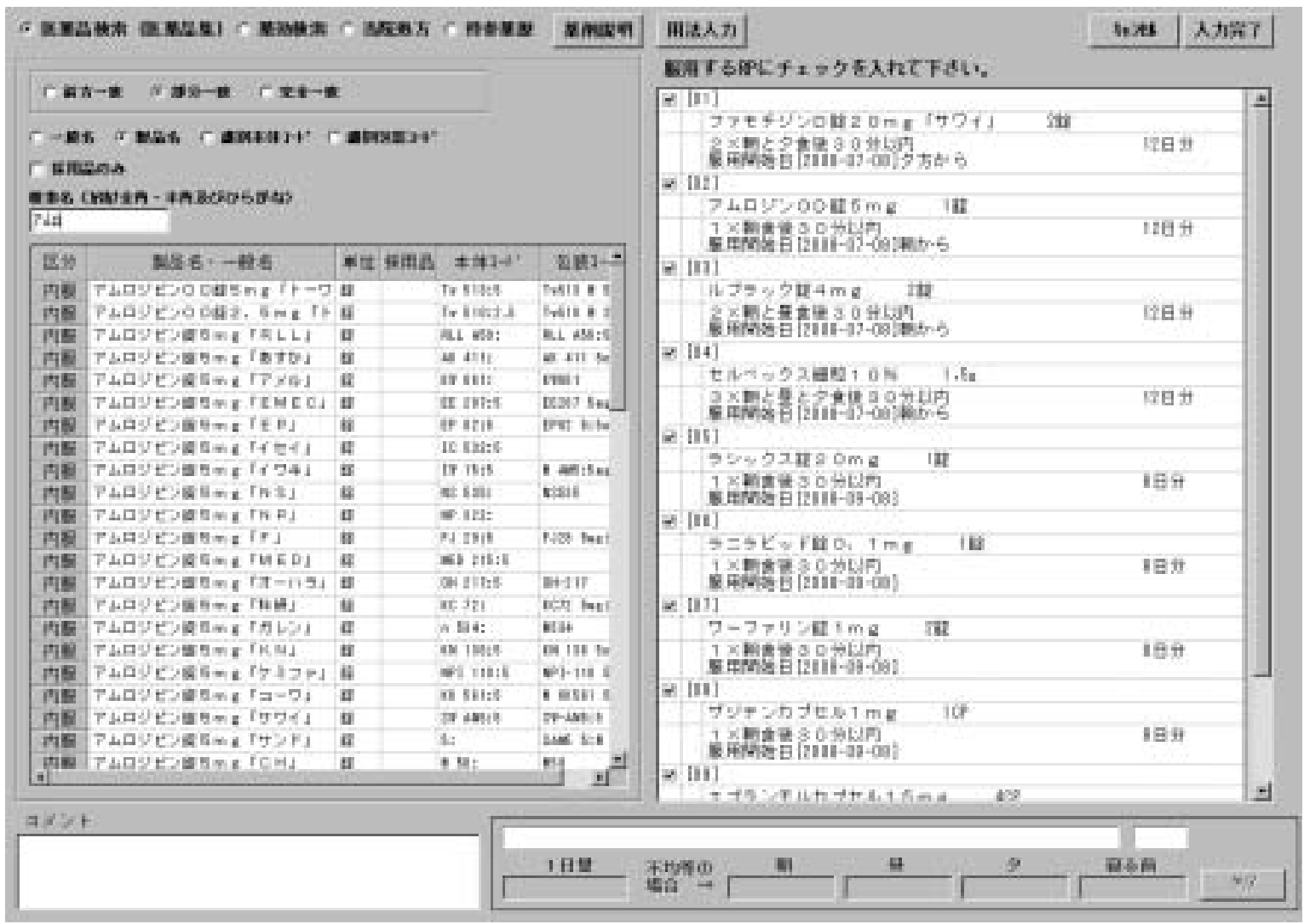

図 2 . 持参薬検索および入力画面(薬㓢師使用画面) 左画面に検索該当医薬品が表示される．医薬品名を選択すると右の用法入力画面が展開される．

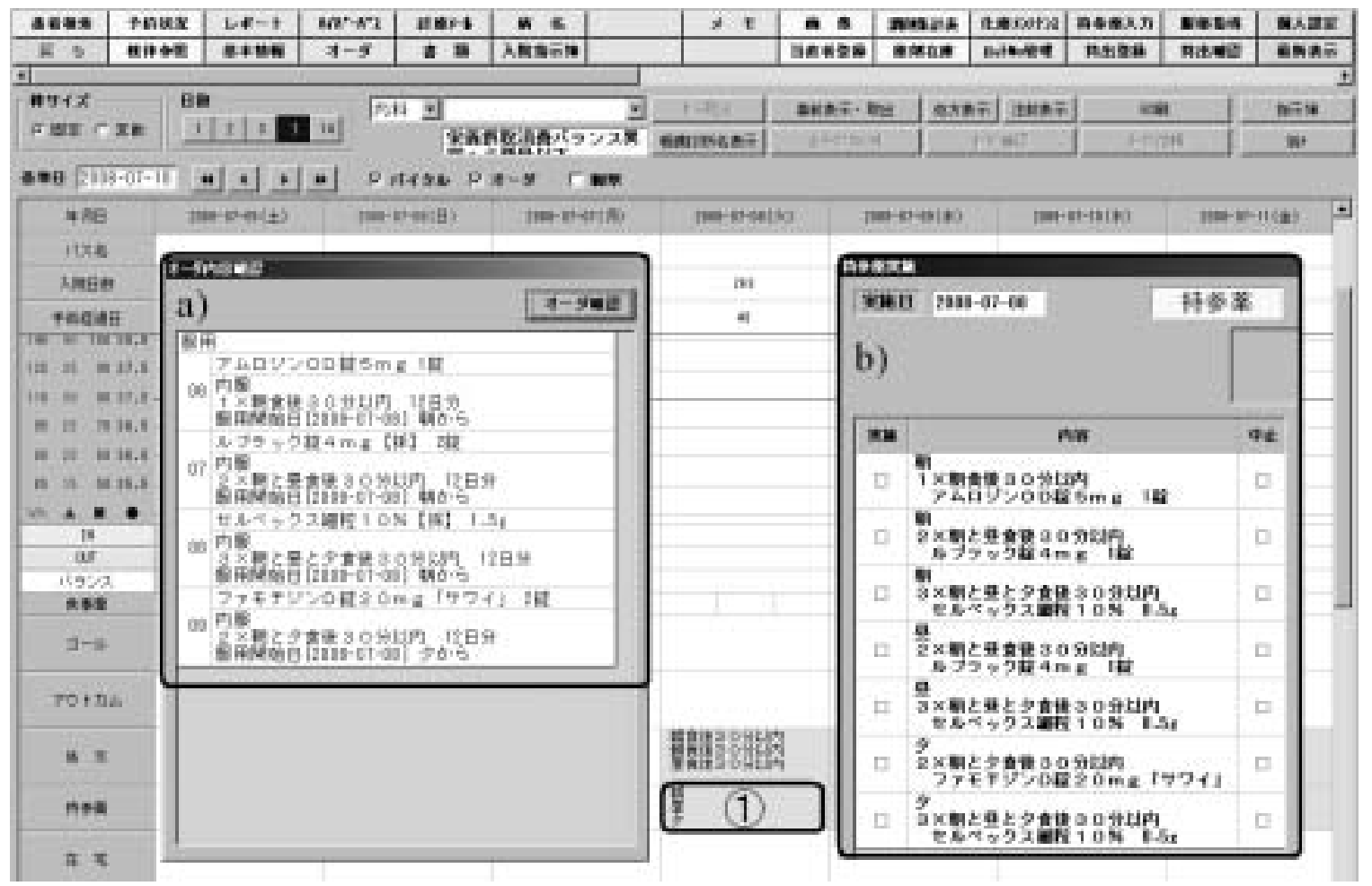

図 3 . 持参薬確認および実施画面(医師・看護師使用画面) a)(1)のタブを左クリックすると a)の一覧画面が表示される . 持参薬が院内採用医薬品と一致す る場合は医薬品名の後に【採】を表示している．

b)(1)のタブを右クリックすると b)の実施画面が表示される . このフィールドで実施確認および 中止処理が可能となる . 
容易となった(図 4).さらに, 持参薬入力系ならびに確 認系のフィールドでは，持参薬名を選択すると医薬品集 が展開され，当該医薬品情報か揤座に閲覧可能なシステ ムとした . 持参薬の再調剂が必要な場合は, 医師が電子 カルテ内の持参薬指示簿に指示内容を入力すると, 持参 薬再調剂指示せんが自動的に発行されるシステムとした (図 5). 薬斉師は再調剂後に持参薬情報を図 2 および図 3 の画面で修正する．なお，薬剂師が持参薬情報を入力 および修正した際は，この情報が自動的に当該患者の担 当医師および看護師に電子カルテのメールで通知される システムとした .

\section{2. 本システムの機能性の評価}

\section{1)対象と調査方法}

本システムの機能性を評価するために，入院診療に携 わる医師および病棟専従の看護師を対象として，2008 年 6 月にアンケート調査を実施した . アンケートは無記 名回答とし, 各設問に対する回答は5 段階の自己評価 で，5：乥う思う，4：やや思う，3：どちらともいえな い, 2: あまり思わない，1：思わない，とした．本研究 は「医療薬学の研究発表における倫理的問題に関する指 針」を遵守し, 本院倫理委員会の承認を得て実施した .

\section{2)CSグラフ}

医師・看護師へのアンケート調査を基に改善すべき点 を明らかにするため, CS 分析を行った ${ }^{23)}$.すなわち各 設問の評点の平均値偏差值(満足度)を縦軸，総合評価と 各設問との相関係数偏差値(重要度)を横軸にして，2次 元座標にプロットした . 加えて , 各設問の評価を位置関 係により視覚化するために偏差值 50(中央值)で境界線を 引き，4象限のCSグラフを作成した．第1象限「重点 維持分野」は満足度および重要度が高く，重点的に維持 していく必要がある範囲とした. 第 2 象限「維持分野」
は満足度が高く, 重要度は低い範囲とした . 第3象限 「改善分野」は満足度および重要度が低い範囲とした。 第 4 象限「重点改善分野」は，満足度は低いが重要度は 高いため, 優先的に改善・解決していく必要がある範囲 とした .

3)CS 分析データ

統計処理には, 統計ソフト EXCEL 品質管理(エスミ (株))を用い, 平均値, 相関係数, 平均値偏差値(式(1)), 相関係数偏差值(式(2)), 交点(50.0, 50.0)から右下 45 度 の斜線に対する角度, 交点からプロット位置までの距離 (式(3))，修正指数(式(4))，改善度(式(5))を求めた。

平均值偏差値 $=10 \times($ 平均値 - 総平均値 $) \div$ 標準偏差 + 50 ……式(1)

相関係数偏差値 $=10 \times($ 相関係数平均値 - 相関係数総 平均值 $) \div$ 相関係数標準偏差 +50 ……式(2) 距離(交点からのプロット位置 $(x, y))$

$$
=\sqrt{(x-\bar{x})^{2}+(y-\bar{y})^{2}}
$$

修正指数 $=(90-$ 角度 $) \div 90$

改善度 $=$ 距離 $\times$ 修正指数

修正指数とは, 交点から右下 45 度の斜線に対して各 プロットがどの程度第 4 象限から離れているかを表す数 值である. 角度が小さいほど修正指数は大きくなり第 4 象限に近づき, 逆に角度が大きいほど修正指数は小さく なり第 4 象限から離れる .すなわち，改善度が高いほど 兴の項目は改善の必要があることが示される. 本研究で は改善度 5 以上を特に重要な課題として対策を講じ，改 善の必要性があると位置付(けた4) .

\section{3. 持参薬継続投与による医薬品購入費の節減額} 2008 年 4 月から 2009 年 1 月における本院の入院患者 数と持参薬鑑別患者数から持参薬を鑑別した患者数の割

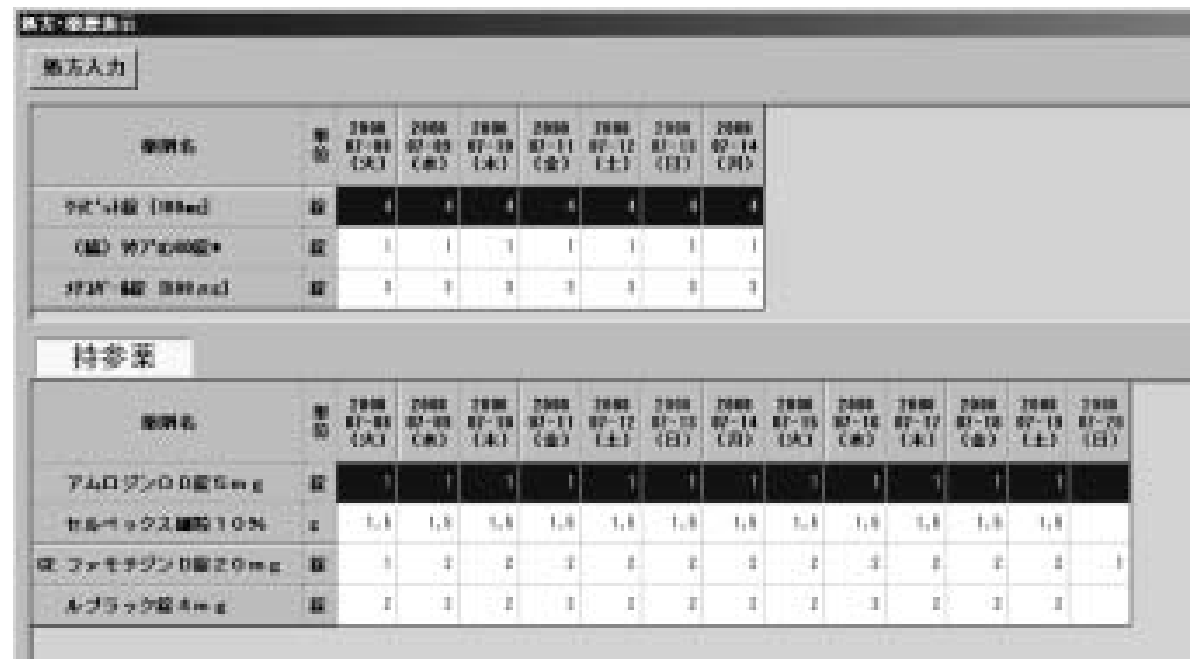

図 4 . 薬歴表示画面 上段の「処方入力」には院内処方薬の薬歴が表示される．下段の「持参薬」 には院内で投与実施した持参薬の薬歴が表示される． 


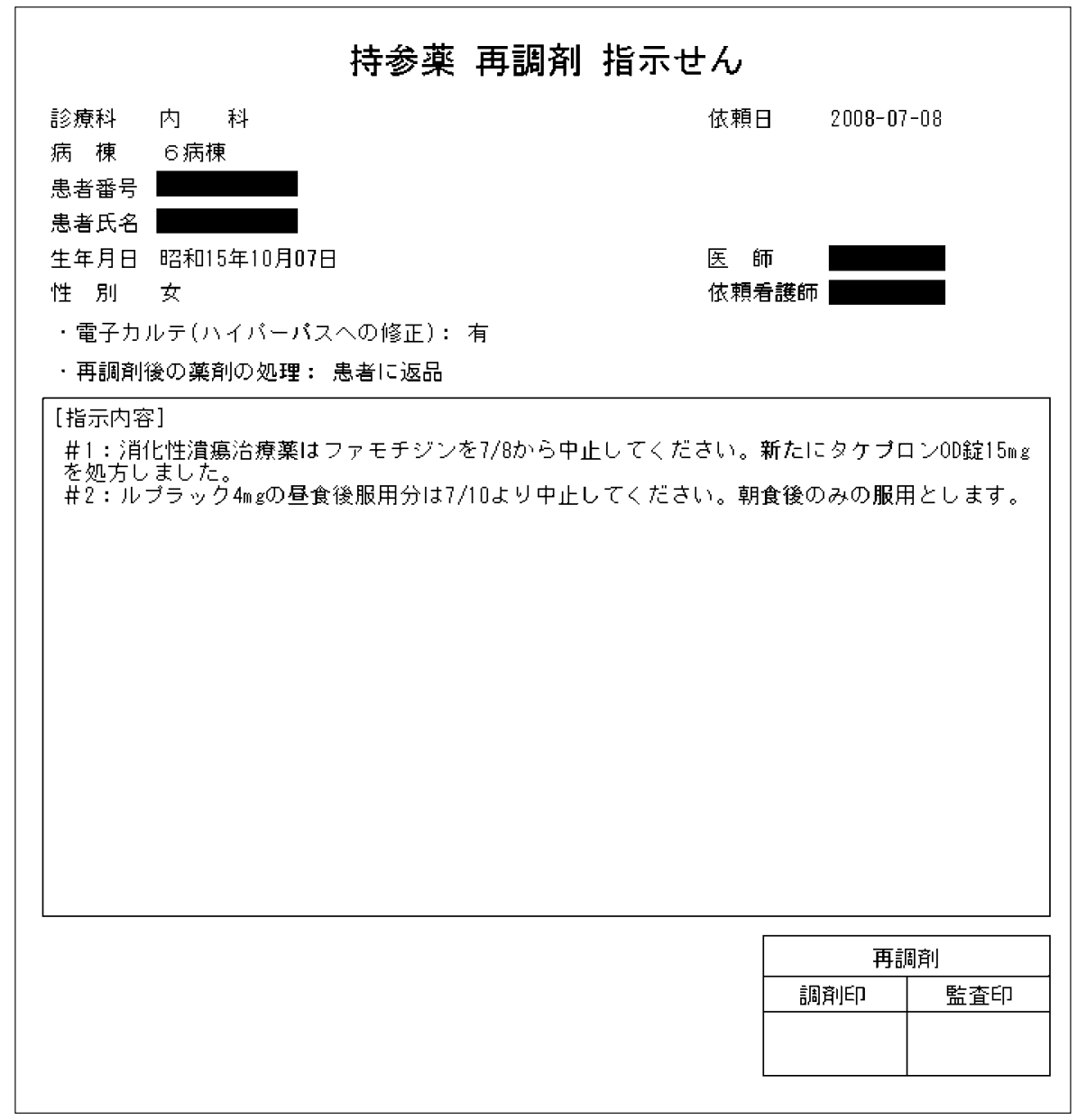

図 5 . 持参薬再調剂指示せん

合(持参薬患者比率)を算出した．次に，本システムで鑑 別した持参薬の金額ならびに実際に持参薬を継続投与し た金額から医薬品購入費の節減額を算出した，光れ攵れ の金額は 2008年 4月時点の薬価基準を用いて算出した . ここで1回使用量が不確定な外用軟亳剂等は除外した .

\section{結＼cjkstart果}

1. 本システムの機能に関する医師・看護師の評価 1)アンケートの回収率

医師 35 名にアンケート用紙を配布し，24 名から有効 回答を得た(回収率 68.6\%)。同樣に，看護師 176 名に配 布し，147 名から有効回答を得た(回収率 83.5\%)．

\section{2) CS 分析}

「本システムの機能性」に関するアンケート評価およ びCS 分析データを弚れ光れ図 6 および表 1 に示す. 「総合評価 : 総合的に本システムは有用だと思います か」(設問 8)の平均値は, 他の設問と比較して医師・看護 師ともに高かった .

2) $-\mathrm{a}$ 医師

CS グラフ(図 7-a) の第 1象限「重点維持分野」には, 「本システムは医師・看護師・薬剂師で持参薬情報の共
有化が図れると思いますか」(設問 4)および「本システム はリスク回避につながると思いますか」(設問 6)がプロッ 卜された．第2象限「維持分野」には，「本システムは 医薬品の有効利用(資源利用)に貢献すると思いますか」 (設問 7)がプロットされた . 第 3象限「改善分野」には, 「採用薬と非採用薬の区別はわかりやすいですか」(設問 2)および「本システムの導入で医師・看護師の専門業務 を行う時間が増えましたか」(設問 3)がプロットされた . 第 4 象限「重点改善分野」には，「本システムを利用す ることで持参薬を規則正しく服用できると思いますか」 (設問 5)がプロットされた . また ,「持参薬の内容は確認 しやすいですか」(設問 1)は平均值偏差值が50であり， 第 1 象限と第 4象限の中点にプロットされた .

改善度は設問 1 の 5.79 が最も高く，次いで設問 3 の 5.28 , 設問 5 の 2.35 , 設問 4 の 1.15 の順であった .

\section{2)- $\mathrm{b}$ 看護師}

CS グラフ(図 7-b)の第 1 象限「重点維持分野」には， 設問 1 ,設問 5 ,設問 6 および設問 7 がプロットされた . 第 2 象限「維持分野」には, 設問 4 がプロットされた .

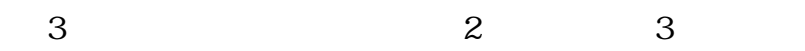
トされた . 第4象限「重点改善分野」にプロットされた 設問はなかった . 
持参薬管理システム(以下, 本システム)の機能性について、その評価をアンヶートで調査することとなりました。 つきましては、各項目に5段階評価(適当な箇所に○印)でお答えください。

\begin{tabular}{|c|c|c|c|c|c|}
\hline & 思わない & $\begin{array}{c}\text { あまり } \\
\text { 思わない }\end{array}$ & $\begin{array}{l}\text { どちらとも } \\
\text { いえない }\end{array}$ & やや思う & そう思う \\
\hline \multicolumn{6}{|l|}{ 【設問1】 } \\
\hline 持参薬の内容は確認しやすいですか。 & 1 & 2 & 3 & 4 & 5 \\
\hline \multicolumn{6}{|l|}{ 【設問2】 } \\
\hline \multicolumn{6}{|l|}{$\begin{array}{l}\text { 採用薬と非採用薬の区別はわかりやすい } \\
\text { ですか。 }\end{array}$} \\
\hline \multicolumn{6}{|l|}{ 【設問3】 } \\
\hline \multirow{2}{*}{\multicolumn{6}{|c|}{$\begin{array}{l}\text { 本システムの導入で医師 ·看護師の専門 } \\
\text { 業務を行う時間が増えましたた。 }\end{array}$}} \\
\hline & & & & & \\
\hline \multicolumn{6}{|l|}{ 【設問4】 } \\
\hline \multicolumn{6}{|l|}{$\begin{array}{l}\text { 本システムは医師・看護師・薬剂師で持 } \\
\text { 参薬情報の共有化が図れると思いますか。 }\end{array}$} \\
\hline \multicolumn{6}{|l|}{ 【設問5】 } \\
\hline \multicolumn{6}{|l|}{$\begin{array}{l}\text { 本システムを利用することで持参薬を規 } \\
\text { 則正しく服用できると思いますか。 }\end{array}$} \\
\hline \multicolumn{6}{|l|}{ 【設問6】 } \\
\hline \multicolumn{6}{|l|}{$\begin{array}{l}\text { 本システムはリスク回避につながると思 } \\
\text { いますか。 }\end{array}$} \\
\hline \multicolumn{6}{|l|}{ 【設問7】 } \\
\hline \multirow{2}{*}{\multicolumn{6}{|c|}{$\begin{array}{l}\text { 本システムは医薬品の有効利用（資源利 } \\
\text { 用）に貢献すると思いますか。 }\end{array}$}} \\
\hline & & & & & \\
\hline \multicolumn{6}{|l|}{ 【設問8:総合評価】 } \\
\hline \multirow{2}{*}{$\begin{array}{l}\text { 総合的に本システムは有用だと思います } \\
\text { か。 }\end{array}$} & 1 & 2 & 3 & 4 & 5 \\
\hline & & L & | & & \\
\hline
\end{tabular}

図 6 . 本システムの機能性に関するアンケート内容と炎の評価 各設問の平均値を Symbol で表示した .

改善度は設問 7 の 3.47 が最も高く，次いで設問 2 の 2.73であったが，改善度 5 以上の設問はなかった .

\section{2. 持参薬継続投与による医薬品購入費の節減額}

2008 年 4 月から 2009 年 1 月の持参薬患者比率の月平 均は 68.3\% であった .この期間に鑑別した持参薬の月 額平均は 3,363,386 円であり, このうち, 月額平均 1,345,473円分の持参薬が継続投与となっており，本院 における医薬品購入費の節減額を明らかにすることがで きた(表 2) .

\section{考察}

入院時の持参薬の管理に関しては, 各施設でさまざま
取り組みがなされており，これによりリスクが回避され た事例や独自に構築した持参薬鑑別システムの有用性に ついて報告されている ${ }^{5-8)}$. しかし, 持参薬鑑別から投 与実施の確認までを包括した持参薬管理システムを構築 し，電子カルテに搭載したとする報告は見あたらない． 本システムの機能性の評価は, 医師・看護師からのア ンケート調査をもとにしたCS 分析により行った . 設問 1の「持参薬の内容は確認しやすいですか」は，医師で

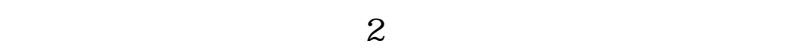
はわかりやすいですか」は，医師・看護師ともにCSグ ラフ上の満足度および重要度が低かった .これらの結果 から，現行の表示で持参薬のうち採用薬と非採用薬の区 別はつくものの，医師・看護師が持参薬の内容を短時間 で正確に把握できるような表示を検討する必要があると 
表 1 . 本システムの機能性における CS 分析データ

\begin{tabular}{|c|c|c|c|c|c|c|c|c|c|}
\hline & & 平均值 & 相関係数 & $\begin{array}{l}\text { 平均値 } \\
\text { 偏差値 }\end{array}$ & $\begin{array}{r}\text { 相関係数 } \\
\text { 偏差値 }\end{array}$ & 角度 & 修正指数 & 距離 & 改善度 \\
\hline \multirow[t]{2}{*}{ 【設問 1】持参薬の内容は確認しやすいですか。 } & 医師 & 3.96 & 0.7733 & 50.00 & 61.58 & 45.00 & 0.500 & 11.58 & 5.79 \\
\hline & 看護師 & 3.76 & 0.5462 & 56.13 & 53.45 & 105.64 & -0.174 & 7.04 & -1.22 \\
\hline \multirow{2}{*}{$\begin{array}{l}\text { 【設問 2】採用薬と非採用薬の区別はわかりや } \\
\text { すいですか。 }\end{array}$} & 医師 & 3.46 & 0.3309 & 35.66 & 32.34 & 95.92 & -0.066 & 22.75 & -1.50 \\
\hline & 看護師 & 3.29 & 0.3712 & 38.86 & 44.79 & 70.06 & 0.222 & 12.30 & 2.73 \\
\hline 【設問 3】本システムの導入で医師・看護師の & 医師 & 3.54 & 0.5810 & 38.05 & 48.87 & 50.40 & 0.440 & 12.01 & 5.28 \\
\hline 専門業務を行う時間が増えましたか。 & 看護師 & 3.09 & 0.0999 & 31.24 & 31.36 & 89.80 & 0.002 & 26.45 & 0.06 \\
\hline 【設問 4】本システムは医師・看護師・薬剤師 & 医師 & 4.13 & 0.7087 & 54.78 & 57.31 & 78.19 & 0.131 & 8.73 & 1.15 \\
\hline で持参薬情報の共有化が図れると思いますか。 & 看護師 & 3.68 & 0.3272 & 53.34 & 42.61 & 159.32 & -0.770 & 8.11 & -6.24 \\
\hline 【設問 5】本システムを利用することで持参薬 & 医師 & 3.83 & 0.6102 & 46.41 & 50.80 & 32.47 & 0.639 & 3.67 & 2.35 \\
\hline を規則正しく服用できると思いますか。 & 看護師 & 3.86 & 0.6814 & 60.20 & 60.14 & 90.16 & -0.002 & 14.38 & -0.03 \\
\hline 【設問 6】本システムはリスク回避につながる & 医師 & 4.38 & 0.7420 & 61.95 & 59.51 & 96.49 & -0.072 & 15.27 & -1.10 \\
\hline と思いますか。 & 看護師 & 3.81 & 0.6439 & 58.17 & 58.28 & 89.59 & 0.005 & 11.63 & 0.05 \\
\hline 【設問 7】本システムは医薬品の有効利用(資源 & 医師 & 4.42 & 0.4407 & 63.15 & 39.60 & 173.35 & -0.926 & 16.77 & -15.53 \\
\hline 利用)に貢献すると思いますか。 & 看護師 & 3.65 & 0.6657 & 52.07 & 59.36 & 57.46 & 0.362 & 9.59 & 3.47 \\
\hline 【設問 8 : 総合評価】総合的に本システムは有 & 医師 & 4.29 & & & & & & & \\
\hline 用だと思いますか。 & 看護師 & 3.84 & & & & & & & \\
\hline
\end{tabular}

平均值偏差值は満足度を，相関係数偏差值は重要度を示す。

a)

\section{平均值偏差値}

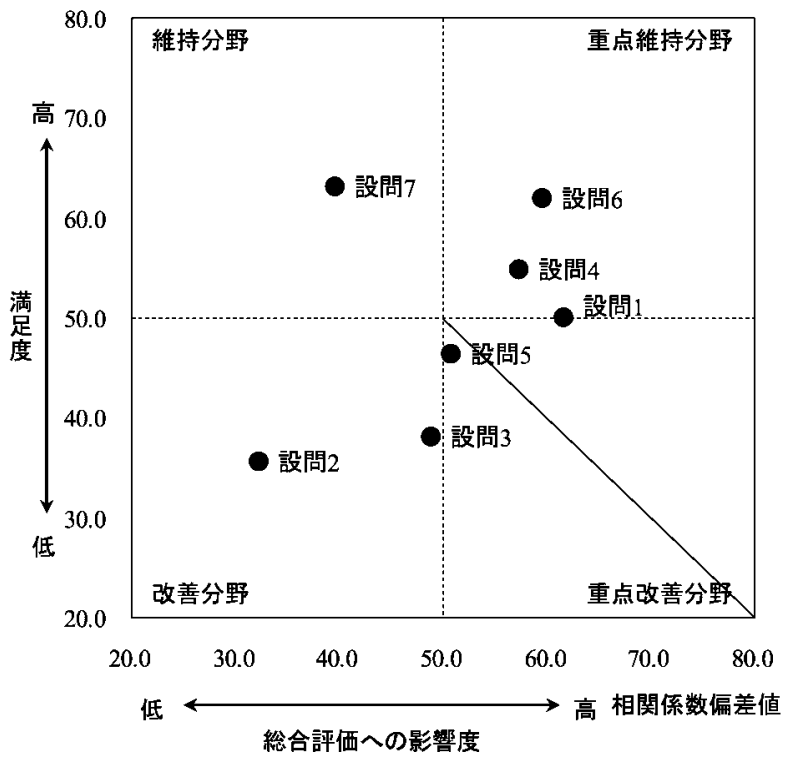

b)

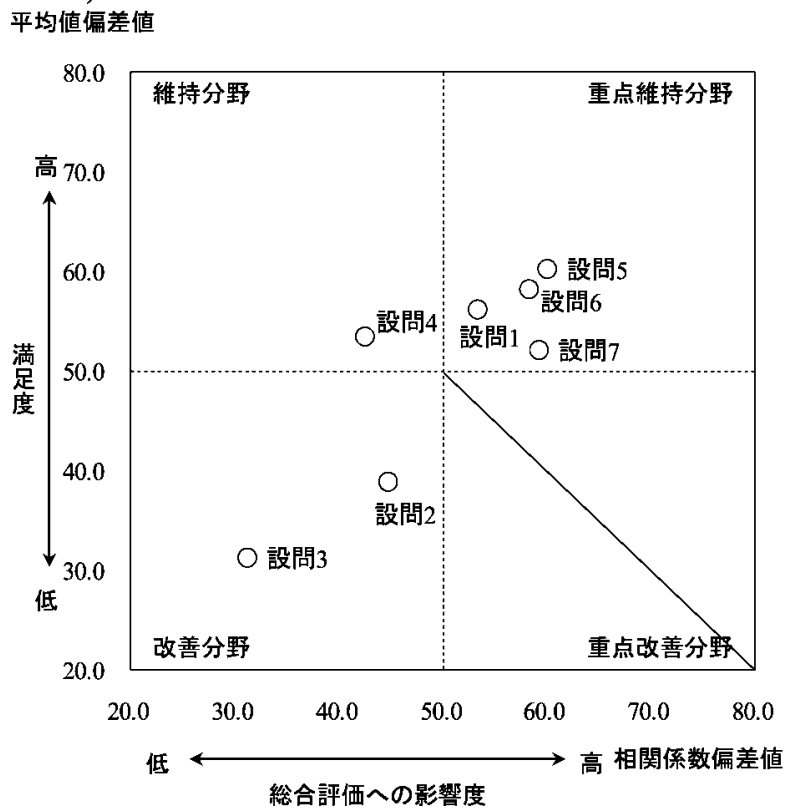

図 7 . 本システムの機能性における CS グラフ

$$
\text { a)医師 b)看護師 }
$$

設問 1 : 持参薬の内容は確認しやすいですか.

設問 2 : 採用薬と非採用薬の区別はわかりやすいですか．

設問 3: 本システムの導入で医師・看護師の専門業務を行う時間か増えましたか.

設問 4 : 本システムは医師・看護師・薬斉師で持参薬情報の共有化が図れると思いますか，

設問 5 : 本システムを利用することで持参薬を規則正しく服用できると思いますか．

設問 6 : 本システムはリスク回避につながると思いますか .

設問 7 : 本システムは医薬品の有効利用(資源利用)に貢献すると思いますか .

設問 8(総合評価)：総合的に本システムは有用だと思いますか． 
表 2 . 持参薬金額ならびに医薬品購入費の節減額

\begin{tabular}{|c|c|c|c|c|c|}
\hline & 入院患者数 & $\begin{array}{c}\text { 持参薬鑑別 } \\
\text { 患者数 }\end{array}$ & $\begin{array}{c}\text { 持参藥患者比率 } \\
(\%)^{*}\end{array}$ & $\begin{array}{c}\text { 持参薬金額 } \\
(\text { 円 })^{* *}\end{array}$ & $\begin{array}{c}\text { 医薬品購入費の } \\
\text { 節減額 }(\text { (円)** }\end{array}$ \\
\hline 2008 年 4 月 & 434 & 274 & 63.1 & $2,474,201$ & $1,040,232$ \\
\hline 2008 年 5 月 & 439 & 291 & 66.3 & $2,474,035$ & $1,005,923$ \\
\hline 2008 年 6 月 & 480 & 311 & 64.8 & $3,267,239$ & $1,204,063$ \\
\hline 2008 年 7 月 & 474 & 353 & 74.5 & $3,249,685$ & $1,184,190$ \\
\hline 2008 年 8 月 & 456 & 311 & 68.2 & $3,098,422$ & $1,237,074$ \\
\hline 2008 年 9 月 & 480 & 324 & 67.5 & $3,284,017$ & 956,526 \\
\hline 2008 年 10 月 & 510 & 342 & 67.1 & $4,317,434$ & $1,999,850$ \\
\hline 2008 年 11 月 & 493 & 358 & 72.6 & $3,907,804$ & $2,038,751$ \\
\hline 2008 年 12 月 & 473 & 311 & 65.8 & $3,375,134$ & $1,186,440$ \\
\hline 2009 年 1 月 & 458 & 337 & 73.6 & $4,185,885$ & $1,601,682$ \\
\hline 平均(/月) & 470 & 321 & 68.3 & $3,363,386$ & $1,345,473$ \\
\hline
\end{tabular}

*(持参薬鑑別患者数 $\div$ 入院患者数 $) \times 100$

** 金額は 2008 年 4 月の薬価基準より算出

考えられる，一方，これまでに薬阂師が持参薬確認を行 うことにより医師・看護師の業務負担軽減になることが 報告されているが ${ }^{100}$, 設問 $3 の 「$ 本システムの導入で 医師・看護師の専門業務を行う時間が増えましたか」 は，医師で改善度が 2 番目に高く，看護師では平均值が 最も低かった .この結果は, 本院が 2006 年から薬剤師 による全入院患者を対象とした持参薬鑑別を実施してい るために，これらは薬剤師の業務としてすでに周知・認 識されていることが大きな要因と考えられた . また , 本 システムの導入により，持参薬内容の確認および実施等 のシステム関連の業務時間が増加していることも要因と して推察され，今後は医師・看護師の持参薬業務に携わ る時間配分を調査し効率化に努めたい，設問 4 の「本シ ステムは医師・看護師・薬剂師で持参薬情報の共有化が 図れると思いますか」は，医師ではCS グラフの第 1 象 限，看護師では第 2 象限にプロットされ，持参薬情報の 共有化か職種間で図れていることが明らかとなった。設 問 5の「本システムを利用することで持参薬を規則正し く服用できると思いますか」は，医師ではCSグラフの 交点付近の第 4 象限にプロットされた . 実際に服薬業務 にかかわる看護師では，満足度が最も高く第 1象限にプ ロットされた．看護師にとって患者へ規則正しく服用さ せることは重要な業務であり，本システムの日付・用法 ごとにカレンダー形式で表示された持参薬情報は看護業 務の軽減につながるものと思われる．また，持参薬の実 施情報は薬歴管理され, 院内処方薬と同樣にカレンダー 形式で投与終了日および残数の把握が可能となったこと が高い評価となった要因と思われる．このことから，本 システムが持参薬の服薬コンプライアンス向上に貢献し ていることが判明した . 持参薬の使用頻度が高くなるほ ど，持参薬に関連するリスクも増大することが予想され る．しかし，設問 6の「本システムはリスク回避につな がると思いますか」は, 医師・看護師の平均值も高く, CSグラフでは第1象限にプロットされた .すなわち， 本システムが持参薬の情報や投与実施に関する管理機能
を有することで，医療事故を回避するシステムであると 評価されていることか理解できた．設問 7 の本システ 厶は医薬品の有効利用(資源利用)に貢献すると思います か」は，医師ではCSグラフの満足度が最も高く第 2 象 限にプロットされた . 看護師ではCSグラフの第 1 象限 にプロットされた .すなわち , 本システムは持参薬の有 効利用に貢献していると評価されていることが示唆され た。

本システムを導入するまでは, 持参薬鑑別患者数なら びに持参薬金額および医薬品購入費の節減額等の情報を 知る手立てがなかったが，導入後はこれらの情報を即座 に把握できるようになった．本研究では，持参薬鑑別患 者数は月平均 321 人, 持参薬患者比率は月平均 $68.3 \%$, 持参薬の継続投与による医薬品購入費の節減額は月額平 均 1,345,473 円であることを明らかにすることができ た .これらは施設規模や診療科の構成に大きく左右され る数値であるが, 全入院患者を対象に行った過去の持参 薬調査研究と比較すると, 本院の持参薬患者比率は高 く，持参薬継続投与による医薬品購入費の節減額は大き かった ${ }^{5,-12)}$.また，医療費負担増加および医薬品購入 費の節減システムを構築することは薬阂師の職能をア ピールするために重要である ${ }^{12)}$. 兴のツールとしても本 システムは有用であり，少なからず病院経営に貢献して いることを証明することができたと考えられる．ところ で, 本システム導入前後で薬剤師の人員および持参薬の 鑑別担当薬斉師に変更はないが, 導入後は持参薬鑑別業 務が省力化されたため, 膠原病・糖尿病外来患者への外 来服薬指導ならびに一部病棟での薬斉師常駐等を始める ことができ，業務を拡大することができた．乥こで今後 は, 本システム導入前後の薬剤師業務に関する評価を実 施予定である .

以上，今回われわれか構筑した持参薬管理システムは 医師・看護師にとって機能的であり，実用性が高いとの 結論を得た 。また，薬闵師が入院早期に持参薬を含めた 医薬品情報を収集することで，必然的に薬物治療への介 
入の機会を得ることができ，相互作用，重複処方および 服薬コンプライアンスを確認することできる .これは， 医薬品の適正使用への貢献および医療安全を配慮した療 養指導に繋がると思われ，薬剂師が果たすべき役割は大 きいと考えられた．今後も，入院時に持参薬を持ち込む 患者は増加すると推察されるが, CS 分析で改善度が高 い項目から優先的に本システムのカスタマイズを行い， 弚の機能を高めていきたい.

\section{引用文献}

1) 古城資久，DPC 時代における病院管理，医薬ジャーナ ル, $41,720-725$ (2005).

2) 相良英憲, 北村佳久, 古野勝志, 柴田和彦, 五味田裕, Customer Satisfaction(CS)分析を応用した実務実習モデ ル・コアカリキュラム実施における改善項目の抽出，医 療薬学，32，295-305 (2006).

3) 辻泰弘, 平木洋一, 神山朝光, 溝口晶子, 佐道紳一, 川 上千秋, 田村康寛, 成末まさみ, 松谷久, 神村英利, 佐々 木均, グループワークによる薬剤管理指導業務オー ディット勉強会の評価, 医療薬学 , 34, 486-495 (2008).

4）菅民郎“，らくらく図解統計分析教室”，才ー八社開発局 編，才ーム社，2006，pp.164-170.

5）渡邊裕之，中井由佳，持参薬鑑別報告書作成支援システ ムの構築と評価, 医療薬学 , 33，913-919 (2007).

6) 金田達也, 田邊靖子, 細川和代, 涌嶋伴之助, 秦英司, 椎木芳和, 寺本圭, 林原正和, 大坪健司, 鳥取大学医学
部附属病院における持参薬の実態と調査業務量の分析 , 医療薬学 , 33, 719-724 (2007).

7）尾上雅英, 赤澤麻衣子, 寺田智祐, 若杉博子, 石津雅弘, 乾賢一，腫瘍外科病棟における持参薬チェックと光の評 価 - 薬剂師による患者面談から内服指示簿までの照合を 通して - , 医療薬学, 32, 424-428 (2006).

8）塩谷明子，高橋佳子, 篠原由貴, 木村知行, 橋元肇, 門 林宗男, 薬斉管理指導業務における持参薬チェックの必 要性, 日本病院薬斉師会雑誌, 41, 1135-1137 (2005).

9) 中村有子, 加茂まどか, 佐藤香織, 穂積雅人, 久道周彦, 後藤順一, 眞野成康, 入院時持参薬の分析結果および医 療スタッフからの評価，医療薬学，34, 522-529 (2008).

10）原千恵子, 小枝正吉,山下恭範, 藤丸サヤ力, 大滝康一, 森田真由美, 小野尚志, 山田武宏, 板垣健太郎, 須野あ づみ, 利岡果美, 石王応知, 村上知子, 朴紘慶, 須野学, 粟屋敏雄, 小川聡, 高橋賢尚, 山本久仁子, 板坦祐一, 千葉 薰, 三好敏之，笠原直邦, 藤田育志, 田崎嘉一, 早勢伸正, 松原和夫, 入院日持参薬チェックは医療の安 全性に寄与する - 持参薬チェック管理薬剤師の役割 - ， 医療薬学, 31, 360-366 (2005).

11）田崎正信, 平野和裕, 齋田哲也, 藤戶博, 入院患者持参 薬の効率的なチェックシステム, 医療薬学，32，12361241 (2006).

12）伊勢雄也, 菅谷量俊, 高田未来, 内田亨, 大下順子, 川 田桂子, 中嶋基広, 片山志郎, 菊池有道, 小森邦子, 千 田英理子, 長谷川幸子, 日本医科大学付属病院における 持参薬チェック業務並びに医療費の節減効果，日本病院 薬斉師会雑誌，42，667-669 (2006). 